Karbol ebenfalls zu der genannten Trypaflavinsalbe über. AuBerdem wird unmittelbar nach dem Kurettement die betr. Stelle einer einmaligen starkfiltrierten Röntgenbestrahlung unterzogen, deren Dosis $10 \mathrm{H}$ betragen soll. Die Erfolge bei dieser Methode sind einwandfrei günstig.

2. Bei impetiginösen Formen empfiehlt sich ebenfalls die 1-2malige Anwendung der Karbolsäure mit nachfolgender Auflage einer $5 \%$ igen roten Karbol-Trypaflavinsalbe.

3. Ist es aber bereits zu atsgedehnter Bildung eines infiltrierten Kreises oder der Guirlande gekommen, so genügt die Karbolbehandlung nicht mehr. Hier wird nun mit Vorteil das ultraviolette Licht (Hg-Lampe, Kontaktbestrahlung der Finsenlampe) und als Nachbehandlung eine Schälkur mittels der desinfizierenden Antisykontinktur, die ich besonders schätzen gelernt habe, angewandt.

4. Bei eitrigen Follikulitiden, tieferen, derberen Infiltraten und Knoten kommt das souveräne Mittel, die Röntgenbestrahlung, in Anwendung, jedoch nur in Form der sehr harten Strahlung, wie ich sie schon vor einer Reihe von Jahren bei der Sykosis zuerst empfahl. Meist genügen zwei, dırch eine dreiwöchige Pause getrennte Sitzungen zur Herbeiführung eines vollen Erfolges. Sehr harte Strahlung, Schwermetallfilter 10,5 Zink oder Kupfer, mit 2-3 mm starkem Aluminiumschutzfilter, Dosis 10-12 H pro Einzelfeld, überkreuzte Bestrahlung ohne Abdeckung der Nachbarfelder. Keinesfalls darf die Schutzabdeckung innerhalb der Barthaargrenze gelegt werden, da es sonst zu häBlicher Demarkation der geschützten Felder kommt. Schon die erste Sitzung muB, gleichsam auf Anhieb, das völlige Defluvium all e $\mathrm{r}$ Barthaare bewirken. Die folgenden dienen nur noch zur Beförderung der Resorption der lnfiltrate und der Rückbildung der Knoten. Die Haare wachsen überall da wieder nach, wo nicht der Krankheitsprozeß selbst eine atrophisierende Veränderung des Haarbodens bewirkt hat.

Die Anwendung von Terpentininjektionen, Opsonogen, Leukogen, von Serum, Pinzettenepilation usw. ist bei diesem Verfahren nicht erforderlich; feuchte Umschläge jeder Art, die bei Mischinfektionen für die Erreger infolge der feuchten Wärme geradezu günstigste Wachstumverhältnisse schaffen, sind zu widerraten.

Jedoch ist die unterstützende Wirkung der Elektrolyse sehr groß. Diese mag alle 14 Tage, solange die Knoten bes tehen, zur Anwendıng kommen, jeder Knoten wird möglichst von verschiedenen Seiten jeweils $1 \frac{1}{2}$ Minute behandelt.

\title{
Meine Behandlung der Trichophytia und Sycosis barbae.
}

Von Dr. J. Wetterer,

Spezialarzt für Haut- und Harnkrankheiten in Mannheim.

Auf Grund ausgedehnter Erfahrungen auf dem Gebiete der Rasiererkrankungen, die die letzten Jahre, hauptsächlich infolge der großen Epidemie Mannheim-Ludwigshafen und Umgebung, brachten und die sich auf mehr als 10000 Fälle erstrecken, môchte ich versuchen, die Behandlung dieser Erkrankungen in ein knappes Schema zu fassen.

Wie ich vorwegnehmend bemerken darf, sind die Ergebnisse bei Befolgung der nachstehend aufgeführten Prinzipien bei Rasiererkrankungen aller Formen und Stadien vorzüglich, in etwa $98 \%$ der Fälle führt die Behandlung sicher zum Ziele.

1. Bei frischen Fällen von Herpes tonsurans habe ich durch zwei-, höchstens dreimalige leichte Betupfung des Herdes mit $\mathrm{Kar}$ bolsäure stets glatte Ábheilung der Affektion ohne Rezidive gesehen. Hierbei wird folgendermaßen vorgegangen:

Der Patient läBt sich rasieren, darauf betupft er die erkrankten Stellen mit heißem W/asser und sodann mit $2 \%$ igem $\beta$-Naphtholspiritus. Dieser Vorbehandlung folgt die Betupfung der Herde mit Acid. carbol. liquefact. von seiten des Arztes. Jeder Herd wird mittelst eines mit Watte bewickelten Holzstäbchens vollständig und über den Rand hinaus damit bestrichen. Er erscheint darauf wie mit Reif bedeckt. Der dũnne, weiße Aetzschorf trocknet rasch ein und bleibt 2 Tage unberührt liegen. Nach dieser Zeit wird rasiert, und zwar nimmt der Patient zuerst die gesunden, am Schlusse erst die kranken Stellen vor. Es folgt nun wiederum eine Betupfung des Herdes mit Karbolsäure, worauf man den Schorf eintrocknen und etwa 3 Tage ruhig liegen läBt; dann wird er mit der bekannten $L$ as $S$ a r schen roten Zinnobersalbe, der ich etwas Trypaflavin $2 \%$ zusetzen lasse, bestrichen und so langsam zur Ablösung gebracht. Die rote Trypaflavinsalbe wird eine Woche lang zur Nachtanwendung beibehalten. Morgens erfolgt eine Betupfung der kranken Stellen mit heißem Wasser und darauf mit $\beta$-Naphtholspiritus. Während dieser zweiten Hälfte der Behandlung lasse man täglich rasieren. Nach Ablauf dieser Zcit ist die Trichophytie in der Regel beseitigt. Serum-, Licht- oder irgendeine andere Behandlung erübrigt sich daher.

Bei Kerion Celsi können wir nicht radikal genug vorgehen: unter Lokalanästhesie wird der ganze Herd kurettiert. Darauf die Ränder und der Herd selbst mit Acid. carbol. liquefact. bestrichen. Nach einigen Tagen gehen wir nach Wiederholung der Aetzung mit 